\title{
Marine Envenomation
}

\author{
Toru Hifumi $^{1}$ (D) $\cdot$ Yoshimune Fukuchi ${ }^{2} \cdot$ Norio Otani $^{1}$
}

Accepted: 25 August 2020 / Published online: 4 September 2020

(C) The Author(s) 2020

\begin{abstract}
With global warming and an increasing frequency of human interaction with venomous marine organisms, physicians are likely to encounter more cases of marine envenomation in clinical practice in Japan and around the world. Few review articles regarding the clinical characteristics of marine envenomation have been published and there has been no comprehensive review of available antivenoms, which are the definitive treatment. We discuss the epidemiology, venom activity, clinical symptoms, diagnosis, and treatment of marine envenomation by the Okinawan box jellyfish, stonefish, Portuguese man-of-war, geography cone, and blueringed octopus. A comprehensive review of available antivenom treatments is also presented.
\end{abstract}

Keywords Marine envenomation $\cdot$ Epidemiology $\cdot$ Diagnosis $\cdot$ Treatment $\cdot$ Antivenom

\section{Background}

The annual incidence of marine envenomation in Florida and eastern Australia is approximately 100,000 [1]. Previous clinical reports of marine envenomation include an outbreak of Portuguese man-of-war envenomation in southeastern Brazil [2] and a compilation of human injuries and fatalities due to envenomation by the geography cone, which is the most dangerous species to humans [3]. Currently, it appears that the incidence of marine envenomation in Japan and around the world is likely to increase due to global warming and increasing frequency of human interactions with venomous marine organisms [4-6]. However, few clinical reviews of marine envenomation have been published [7-9], and there has been no comprehensive review of available antivenoms, which are

This article is part of the Topical Collection on Medicine

Toru Hifumi

hifumitoru@gmail.com

Yoshimune Fukuchi

fukuchyo@pref.okinawa.lg.jp

Norio Otani

oono@luke.ac.jp

1 Department of Emergency and Critical Care Medicine, St. Luke's International Hospital, Emergency Medical Center, 9-1 Akashi-cho, Chuo-ku, Tokyo 104-8560, Japan

2 Okinawa Prefectural Institute of Health and Environment, Okinawa, Japan the definitive treatment. In this review, we discuss the epidemiology, venom activity, clinical symptoms, diagnosis, and treatment of marine envenomation by the box jellyfish, stonefish, Portuguese man-of-war, geography cone, and blueringed octopus and also provide a comprehensive review of available antivenoms.

\section{Main Text}

\section{Box Jellyfish}

Scientific name: Chironex yamaguchii

Appearance: The diameter of the hood is approximately $10-14 \mathrm{~cm}$, and the body length can reach approximately $1.5 \mathrm{~m}$ with tentacles extended. This jellyfish possesses seven tentacles attached to four arms (Fig. 1).

Epidemiology: Jellyfish appear in large numbers in swimming areas, particularly inlets and beaches where waves are subdued. Several jellyfish sting cases have been reported in the literature [10-12] and recently, Hifumi et al. comprehensively described the clinical characteristics of jellyfish stings in Japan [13]. One urban emergency department in Hawaii experiences approximately 20 jellyfish sting cases annually [14]. The annual number of cases in Japan is relatively small compared with the annual incidence of approximately 100,000 in Florida and eastern Australia [1].

Venom activity and clinical symptoms: Box jellyfish venom has hemolytic and neurotoxic effects and causes skin necrosis and hypotension. 


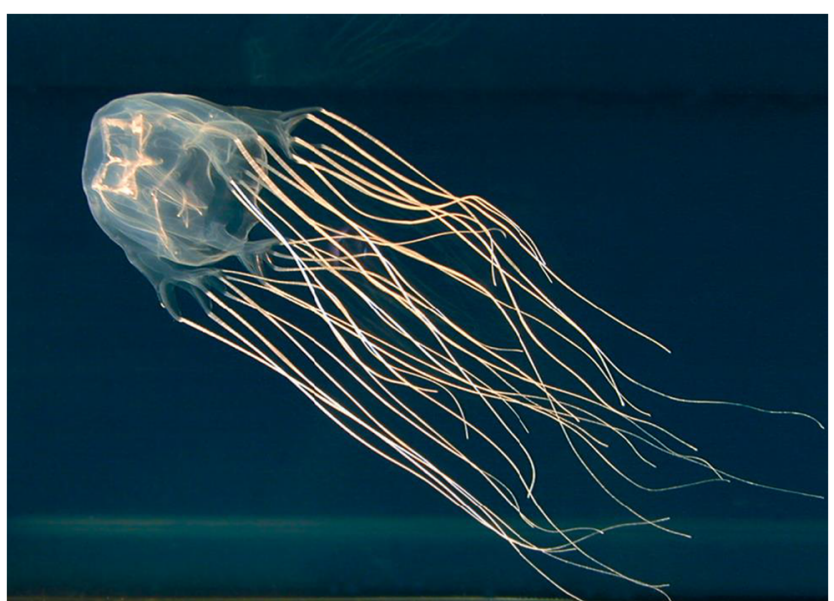

Fig. 1 Box Jellyfish. Photograph courtesy of the Okinawa Prefectural Institute of Health and Environment

Diagnosis: No definite diagnostic criteria exist. Diagnosis of jellyfish stings is based on either the patient's history or positive identification of the responsible jellyfish presented by the patient [13]. Severe stings result in systemic envenomation, which may result in Irukandji syndrome and/or anaphylaxis, and most often require hospital admission [15].

Treatment: Applying vinegar to any tentacles remaining on the skin prior to removal can deactivate unfired nematocysts. After vinegar application, the tentacles may be gently removed. Cardiac arrest and cardiogenic shock are appropriate indications for antivenom administration [16]; earlier administration of antivenom may neutralize the venom.

Prevention: Box jellyfish are a common hazard, as they are translucent and difficult to see through the water's surface. Swimming within an area protected by anti-jellyfish barrier netting is recommended.

\section{Stonefish}

\section{Scientific name: Synanceia verrucosa}

Appearance: Reef stonefish have an overall body length of approximately $40 \mathrm{~cm}$ and are difficult to see, as they blend in with rocks on the seabed. Their spines are tough and able to penetrate rubber-soled boots and wetsuits (Fig. 2).

Epidemiology: Stonefish stings, including those from reef stonefish, are a common injury seen in the emergency room. They are primarily found in the coastal waters of the IndoPacific region, including the USA, Australia, Malaysia, Hong Kong, and Singapore [17-21]. Few Japanese studies of stonefish envenomation have been reported [22, 23]; however, Hifumi et al. recently reported 15 cases over a 5 -year observation period [24] and two deaths related to stonefish envenomation have been reported in Japan [25].

Venom activity and clinical symptoms: Fatalities resulting from reef stonefish stings have been reported in Okinawa prefecture. These injuries may have been sustained

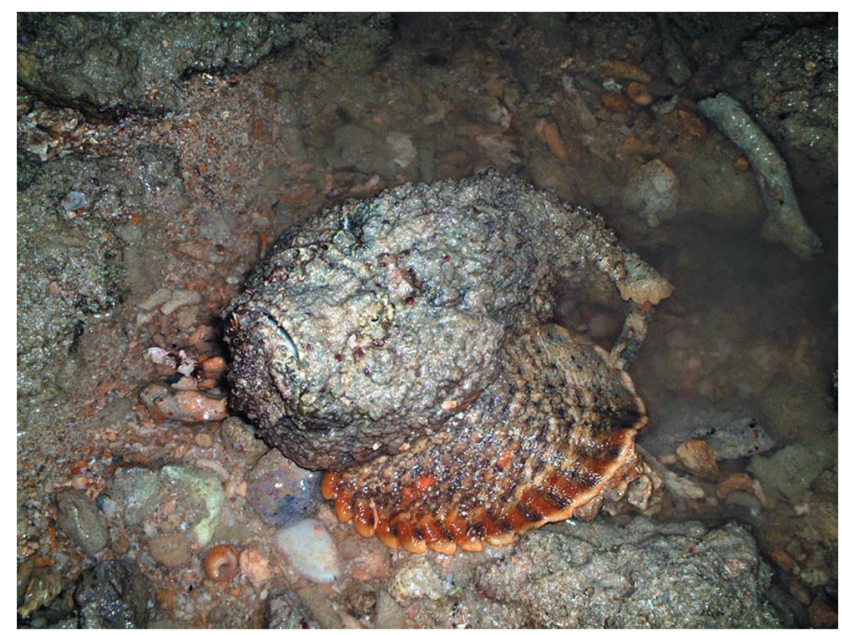

Fig. 2 Stonefish. Photograph courtesy of the Okinawa Prefectural Institute of Health and Environment

by individuals fishing for food, since stonefish are eaten in some regions. Venom from the genus Synanceia has hyaluronidase activity and causes hemolysis, hypotension, and nerve paralysis.

Diagnosis: Currently, there are no definitive diagnostic criteria for stonefish envenomation. The diagnosis of stonefish envenomation is based on the patient's history or the positive identification of the stonefish presented by the patient [24].

Treatment: It is important to warm the site of stonefish stings as this helps to relieve pain. Warming the affected area to approximately $43{ }^{\circ} \mathrm{C}$ is recommended. Antivenom is available and consists of the purified $\mathrm{F}(\mathrm{ab}) 2$ fragment of equine IgG antibodies raised against the venom of Synanceia trachynis [26]. In a study conducted in Hong Kong, 25\% of patients received treatment with antivenom [21].

Prevention: Use thick rubber-soled footwear to prevent spine penetration.

\section{Portuguese Man-of-War}

\section{Scientific name: Physalia physalis utriculus}

Appearance: A lovely blue hue. Also called "blue bottles," they have a bluish-white floating hood from which tentacles extend to reach a length of 10-20 m [27]. The Portuguese man-of-war is also called the "electric jellyfish" because its tentacles contain many nematocysts that induce a strong sensation akin to an electric shock (Fig. 3).

Epidemiology: An outbreak of Portuguese man-of-war envenomation in southeastern Brazil was reported in 2013 [2]. In addition, a massive outbreak at Yuigahama Beach, Japan, occurred in 2018.

Venom activity and clinical symptoms: Portuguese manof-war venom induces hemolysis, swelling, and necrosis and can be lethal. Extreme pain is experienced immediately following the sting. Areas of skin that contact the man-of-war's 


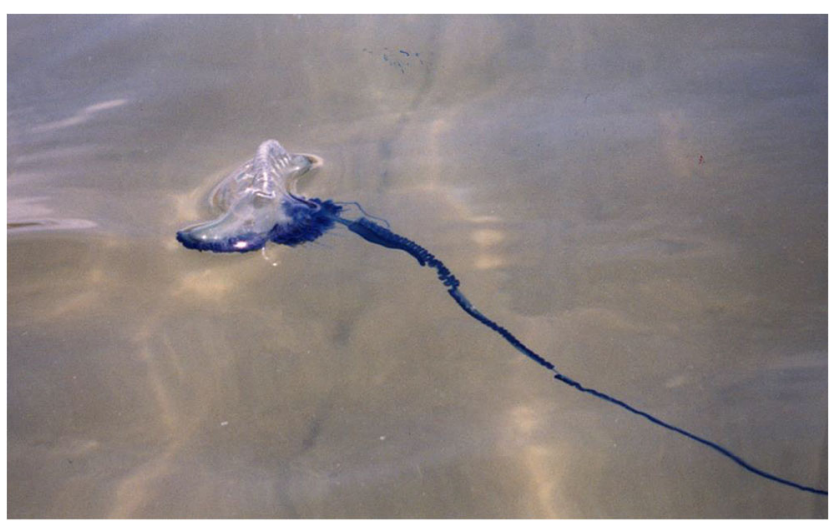

Fig. 3 Portuguese man-of-war. Photograph courtesy of the Okinawa Prefectural Institute of Health and Environment

tentacles form swollen welts that appear as a linear papular rash.

Diagnosis: Currently, there are no definitive diagnostic criteria for Portuguese man-of-war envenomation. The diagnosis is based on the patient's history or positive identification of the Portuguese man-of-war presented by the patient.

Treatment: Use sea or tap water to wash away any tentacles that remain wrapped around the body. If tentacles cannot be rinsed off, gently remove them with the fingertips. Do not use vinegar as you would for box jellyfish stings because this promotes nematocyst firing in the Portuguese man-of-war. Use strong topical steroids if inflammation at the site of the sting is severe.

Prevention: Do not enter the ocean when alerted to the presence of jellyfish. Swim in areas protected by an antijellyfish barrier net. Minimize exposure of unprotected skin as much as possible.

\section{Geography Cone}

\section{Scientific name: Gastridium geographus}

Appearance: The shell of the geography cone grows to a size of 10-13 cm and it beautifully intertwines clouds of crimson with a fine mesh pattern (Fig. 4).

Epidemiology: Araki et al. reported 18 cases from Okinawa prior to 1991; 13 were from G. geographus envenomation, of which 4 were fatal [28]. Kohn reported 43 cases of victim, of which 15 (35\%) were fatal [3].

Venom activity and clinical symptoms: G. geographus is the most dangerous species known to humans [3]. Conotoxins target receptors and channels that mediate neuromuscular blockade [29]. Paralysis at the site of injury, dizziness, double vision, numbness of the mouth, and other symptoms may occur. In severe cases, ventilatory support may be required.

Diagnosis: Currently, there are no definitive diagnostic criteria for geography cone envenomation. The diagnosis is based on the patient's history or the positive identification of the geography cone presented by the patient.

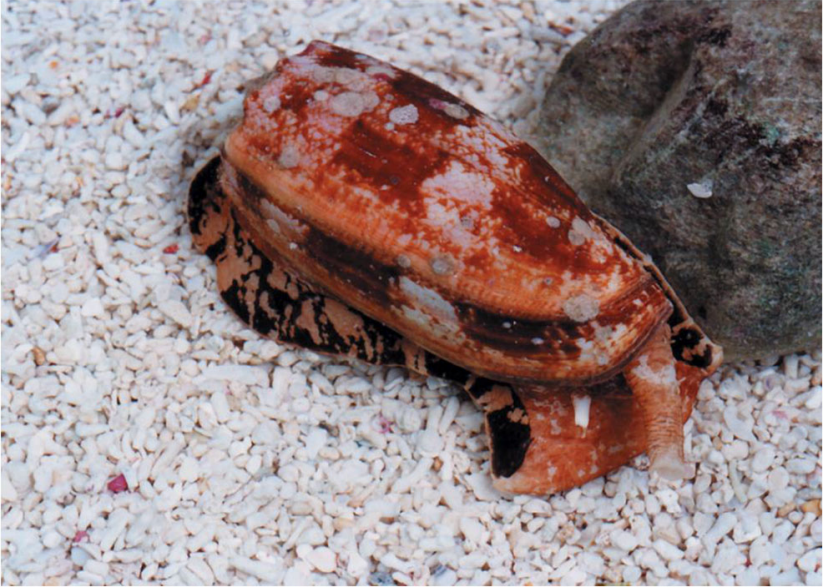

Fig. 4 Geography cone. Photograph courtesy of the Okinawa Prefectural Institute of Health and Environment

Treatment: The wound should be soaked in hot water (maximum $45^{\circ} \mathrm{C}$ ) for 30-90 min [7]. Standard medical care should be provided. Mechanical ventilation may be required in severe cases. There is no antivenom for a geography cone sting. Treatment is supportive until the toxins become inactive.

Prevention: Do not pick up seashells carelessly.

\section{Blue-Ringed Octopus}

Scientific name: Hapalochlaena fasciata

Appearance: A small octopus approximately $10 \mathrm{~cm}$ in length. The skin is yellow and spotted with blue circles [30] (Fig. 5).

Epidemiology: H. fasciata is most commonly found around intertidal rocky shores and coastal waters between Australia and through the Pacific Ocean north to Japan.

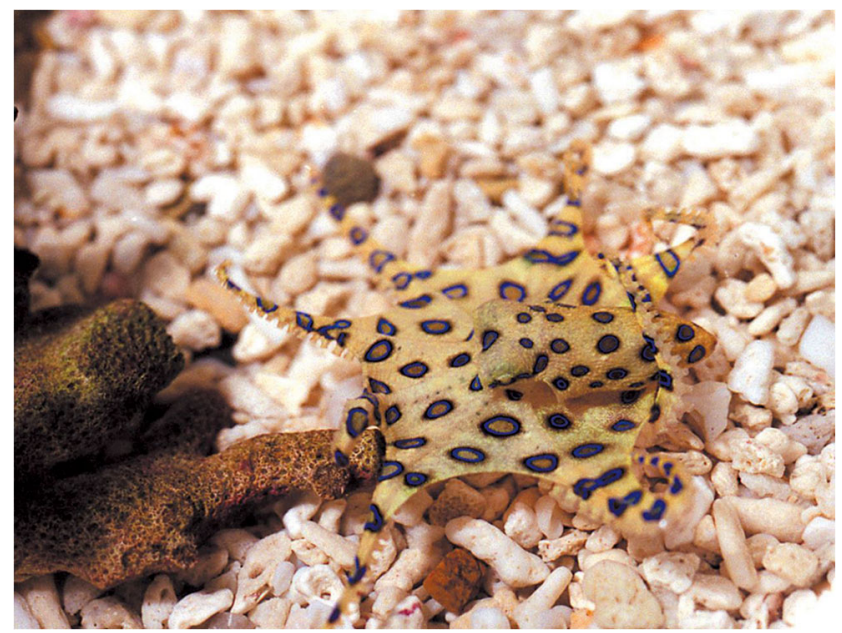

Fig. 5 Blue-ringed octopus. Photograph courtesy of the Okinawa Prefectural Institute of Health and Environment 
Table 1 Clinical availability and indication of antivenom

\begin{tabular}{llllll}
\hline & Box jellyfish & Stonefish & $\begin{array}{l}\text { Physalia } \\
\text { physalis }\end{array}$ & $\begin{array}{l}\text { Conus } \\
\text { geographus }\end{array}$ & $\begin{array}{l}\text { Blue- } \\
\text { lined } \\
\text { octopus }\end{array}$ \\
\hline $\begin{array}{c}\text { Clinical } \\
\text { avail- } \\
\text { ability }\end{array}$ & Yes & Yes & No & No & No \\
$\begin{array}{c}\text { Indication } \\
\begin{array}{c}\text { Cardiac } \\
\text { arrest or } \\
\text { cardiogen- } \\
\text { ic shock }\end{array}\end{array}$ & $\begin{array}{c}\text { Systemic effects and those with severe } \\
\text { pain that is unresponsive to hot water } \\
\text { immersion and analgesia }\end{array}$ & - & - & - \\
& & & & \\
\hline
\end{tabular}

Venom activity and clinical symptoms: Blue-ringed octopus venom includes tetrodotoxin and can cause respiratory muscle paralysis [30].

Treatment: Standard medical care should be provided. Mechanical ventilation may be required in severe cases.

Prevention: The blue-ringed octopus may be found during clam digging when large rocks are overturned. They should not be touched with bare hands.

\section{Antivenom}

Clinical availability of antivenoms and indications for their use are summarized in Table 1 [31]. Only antivenoms for jellyfish and stonefish stings are available. Both are manufactured by immunizing horses against unbound venom; therefore, adverse reactions, including anaphylaxis, should be anticipated and prepared for. The incidence of adverse reactions to snake antivenom produced from horse serum is 2.4 $11 \%$ [32]. The establishment of airway, breathing, and circulation is required before using antivenom. This section may be divided by subheadings. It should provide a concise and precise description of the experimental results, their interpretation, and the experimental conclusions that can be drawn.

\section{Conclusions}

This review provides a comprehensive summary of the available information regarding marine envenomation in humans. Data continue to be collected on a case-by-case basis as no large-scale epidemiological studies have been conducted to date. Clinical marine envenomation research is severely lacking. Since more cases of marine envenomation will undoubtedly occur in the future, emergency physicians need to be aware of their diagnosis and management.

Authors' Contributions Conceptualization, T.H.; writing - original draft preparation, T.H.; writing - review and editing, Y.F and N.O; visualization, T.H.; supervision, Y.F. and N.O. All authors have read and agreed to the published version of the manuscript.
Funding This research was supported by the Research Program on Emerging and Re-emerging Infectious Disease from the Japan Agency for Medical Research and Development (AMED). This research received no external funding.

Data Availability Not applicable.

\section{Compliance with Ethical Standards}

Ethical Approval and Consent to Participate Not applicable.

Consent for Publication Not applicable.

Competing Interests The authors declare that they have no competing interests.

Open Access This article is licensed under a Creative Commons Attribution 4.0 International License, which permits use, sharing, adaptation, distribution and reproduction in any medium or format, as long as you give appropriate credit to the original author(s) and the source, provide a link to the Creative Commons licence, and indicate if changes were made. The images or other third party material in this article are included in the article's Creative Commons licence, unless indicated otherwise in a credit line to the material. If material is not included in the article's Creative Commons licence and your intended use is not permitted by statutory regulation or exceeds the permitted use, you will need to obtain permission directly from the copyright holder. To view a copy of this licence, visit http://creativecommons.org/licenses/by/4.0/.

\section{References}

1. Burnett JW. Human injuries following jellyfish stings. Md Med J. 1992;41:509-13.

2. Haddad V Jr, Virga R, Bechara A, Silveira FL, Morandini AC. An outbreak of Portuguese man-of-war (Physalia physalis - Linnaeus, 1758) envenoming in Southeastern Brazil. Rev Soc Bras Med Trop. 2013;46:641-4.

3. Kohn AJ. Human injuries and fatalities due to venomous marine snails of the family Conidae. Int J Clin Pharmacol Ther. 2016;54: 524-38.

4. Hifumi T. Treatments of venomous snake bites. Nihon Iji Shinpo. 2015;4772:56.

5. Xu Y, Ramanathan V, Victor DG. Global warming will happen faster than we think. Nature. 2018;564:30-2.

6. Needleman RK, Neylan IP, Erickson TB. Environmental and ecological effects of climate change on venomous marine and 
amphibious species in the wilderness. Wilderness Environ Med. 2018;29:343-56.

7. Hornbeak KB, Auerbach PS. Marine envenomation. Emerg Med Clin North Am. 2017;35:321-37.

8. Little M, Pereira P, Mulcahy R, Cullen P. Marine envenomation. Emerg Med (Fremantle). 2001;13:390-4.

9. Perkins RA, Morgan SS. Poisoning, envenomation, and trauma from marine creatures. Am Fam Physician. 2004;69:885-90.

10. Kawahara M, Uye S, Burnett J, Mianzan H. Stings of edible jellyfish (Rhopilema hispidum, Rhopilema esculentum and Nemopilema nomurai) in Japanese waters. Toxicon. 2006;48: 713-6.

11. Manabe Y, Mabuchi T, Kawai M, Ota T, Ikoma N, Ozawa A, et al. A case of delayed flare-up allergic dermatitis caused by jellyfish sting. Tokai J Exp Clin Med. 2014;39:90-4.

12. Ohtaki N, Satoh A, Azuma H, Nakajima T. Delayed flare-up reactions caused by jellyfish. Dermatologica. 1986;172:98-103.

13. Hifumi T, Fukuchi Y, Otani N, Kondo Y, Kitamoto T, Kobayashi $\mathrm{K}$, et al. Clinical characteristics of jellyfish stings in Japan. Acute Med Surg. 2020;7:e469.

14. Ping J, Onizuka N. Epidemiology of jellyfish stings presented to an American urban emergency department. Hawaii Med J. 2011;70: 217-9.

15. Fenner PJ. Jellyfish responsible for Irukandji syndrome. QJM. 2006;99:802-3 author reply 3-4.

16. Isbister GK. Jellyfish stings. Aust Prescrib. 2007;30.

17. Tay TK, Chan HZ, Ahmad TS, Teh KK, Low TH, Wahab NA. Stonefish envenomation of hand with impending compartment syndrome. J Occup Med Toxicol. 2016;11:23.

18. Ngo SY, Ong SH, Ponampalam R. Stonefish envenomation presenting to a Singapore hospital. Singap Med J. 2009;50:506-9.

19. Prentice O, Fernandez WG, Luyber TJ, McMonicle TL, Simmons MD. Stonefish envenomation. Am J Emerg Med. 2008;26:972 e12.

20. Isbister GK. Venomous fish stings in tropical northern Australia. Am J Emerg Med. 2001;19:561-5.
21. Poon KM. CHVNaMT. A 10-year retrospective review of stonefish sting injury in Hong Kong. Hong Kong J Emerg Med. 2019:1-4.

22. Yamamoto R, Suzuki M, Hori S, Aikawa N. Stonefish "Okoze" envenomation during food preparation. Keio J Med. 2010;59:1922.

23. Hashimoto A, Nakao A, Inoue T, Fuse C, Yamada T, Hirata J, et al. Incorrect first aid treatment information about stonefish envenomation on medical websites. Chudoku Kenkyu. 2013;26:292-4.

24. Hifumi T. Clinical characteristics of stonefish "Oni-DarumaOkoze" envenomation in Japan. Acute Med Surg. 2020;7:e496.

25. Azama Y, Morine N, Tsuha A, Kudaka J. Injury cases by Marine A nimalnimals in Okinawa , Japan in 2012-2013. Okinawa Eisei kenkyujo-Hou. 2016:33-7.

26. Church JE, Hodgson WC. Stonefish (Synanceia trachynis) Antivenom: in vitro efficacy and clinical use. J Toxicol Toxin Rev. 2003:69-76.

27. Munro C, Vue Z, Behringer RR, Dunn CW. Morphology and development of the Portuguese man of war, Physalia physalis. Sci Rep. 2019;9:15522.

28. Araki Y, Fukumura K, Yoshiba S. Conus-stings in Okinawa. Jpn J Trop Med Hyg. 1992;20:63-4.

29. Espiritu DJ, Watkins M, Dia-Monje V, Cartier GE, Cruz LJ, Olivera BM. Venomous cone snails: molecular phylogeny and the generation of toxin diversity. Toxicon. 2001;39:1899-916.

30. Townsend KA, Altvater J, Thomas MC, Schuyler QA, Nette GW. Death in the octopus' garden: fatal blue-lined octopus envenomations of adult green sea turtles. Mar Biol. 2012;159: 689-95.

31. CSL Antivenom Handbook. http://www.toxinology.com/generic static_files/cslavh_antivenom_stonefish.html

32. Hifumi T, Sakai $\bar{A}$, Kondo $\bar{Y}$, Yamamoto A, Morine N, Ato M, et al. Venomous snake bites: clinical diagnosis and treatment. J Intensive Care. 2015;3:16.

Publisher's Note Springer Nature remains neutral with regard to jurisdictional claims in published maps and institutional affiliations. 